\title{
Towards a calibration of building energy models: A case study from the Spanish housing stock in the Mediterranean climate
}

\section{Hacia una calibración de modelos energéticos: Caso de estudio del parque residencial español en clima mediterráneo}

T. Blázquez ${ }^{(*)}$, R. Suárez ${ }^{(*)}, \underline{\text { J. J. Sendra }}{ }^{(*)}$

\section{ABSTRACT}

Current energy policies focus on retrofitting to achieve Horizon 2020 aims, especially concerning the residential stock constructed before the first thermal regulations. According to this, improving energy efficiency and interior comfort conditions in buildings must be supported by the knowledge of its real energy performance. Due to uncertainty and the lack of information on the current energy performance of housing and its real operational conditions, discrepancies between the results obtained and the measured data arise. Housing monitoring under real occupational conditions become essential for a better understanding of environmental behavior of residential building stock.

Our aim is to show the calibration process, based on monitoring data obtained from a group of dwellings of national heritage interest built in the 1950 os in Seville (a Mediterranean climate city). Calibration allows simulation results to approximate to current environmental conditions, aiming to predict and optimize the potential for subsequent environmental and energy implementation.

Keywords: Calibration; energy models; monitoring; residential stock; retrofitting; simulation.

\section{RESUMEN}

Las actuales políticas energéticas europeas proponen la rehabilitación para poder alcanzar los objetivos del Horizonte 2020, especialmente del parque residencial construido antes de las primeras normativas térmicas, debiendo cimentarse la mejora en eficiencia energética y confort en el conocimiento de su comportamiento energético real. Aparecen divergencias entre resultados reales y de simulación debido a las incertidumbres y falta de información sobre el estado actual y las condiciones reales de uso y operacionales. La monitorización bajo condiciones de ocupación real resulta imprescindible para conocer el comportamiento energético y ambiental del parque residencial.

Nuestro objetivo es mostrar el proceso de calibración de modelos energéticos, a partir de la monitorización, de unas viviendas de interés patrimonial construidas en los años cincuenta en Sevilla, ciudad de clima mediterráneo. La calibración permite aproximar los resultados de simulación a las condiciones ambientales reales, para predecir y optimizar el potencial de mejora ambiental y energética en la rehabilitación.

Palabras clave: Calibración; modelos energéticos; monitorización; parque residencial; rehabilitación; simulación.

(*) Instituto Universitario de Arquitectura y Ciencias de la Construcción, ETSA - Universidad de Sevilla (España). Persona de contacto/Corresponding author: jsendra@us.es (J. J. Sendra)

Cómo citar este artículo/Citation: Blázquez, T., Suárez, R., Sendra, J. J. (2015). Towards a calibration of building energy models: A case study from the Spanish housing stock in the Mediterranean climate. Informes de la Construcción, 67(540): e128, doi: http://dx.doi. org/10.3989/ic.15.081.

Licencia / License: Salvo indicación contraria, todos los contenidos de la edición electrónica de Informes de la Construcción se distribuyen bajo una licencia de uso y distribución Creative Commons Reconocimiento no Comercial 3.o. España (cc-by-nc). 
1st Prize - Journal Informes de la Construcción for the best paper of the "II International and IV National Congress on Sustainable Construction \& Eco-Efficient Solutions”, Seville (Spain) May 25-27, 2015.

\section{INTRODUCTION}

Almost 55 \% of the existing housing stock in Spain (1) belongs to residential buildings pre-dating the introduction of the Basic Building Regulation on Thermal Conditions in Buildings in 1979. This regulation made the installation of thermal insulation in building envelopes compulsory. These buildings present poor energy performance and high energyconsumption rates, which in most cases lead to situations of "energy poverty" among their residents (2), especially in the case of social housing. Focusing on energy retrofitting actions throughout this building stock is a priority both at European (3) and Spanish level (4), as habitability and comfort conditions in them are far from meeting current energy standards, so that there is great potential for improvement.

Housing energy refurbishment projects use different simulation software tools to assess and analyze the current conditions of housing, as well as to predict a reduction in energy demand and consumption to obtain better energy ratings, by applying various refurbishment strategies, which may affect either the building envelope or installations and energy consuming equipment. However, due to the high number of parameters involved, energy models show major uncertainties, which limit the viability of results and prevent reliable conclusions on the potential improvement from energy refurbishment projects.

It is well known that there are discrepancies, in some cases fairly significant, between in situ data measurements of environmental and energy parameters in the residential units, and results from simulations using software tools accredited by the scientific community (5) (6). In fact, one of the themes proposed by the European Commission in its research and innovation policy Horizon 2020 is "New tools and methodologies to reduce the gap between predicted and actual energy performances at the level of buildings and blocks of buildings" (7).

The main aim of this paper focuses on this framework. We aim to reduce the discrepancy between predictions and actual energy performance by calibrating energy models using in situ measured data in occupied residential units, that is, in real-time operating and occupancy conditions.

A thorough literature review on the calibration of whole building energy simulation case studies carried out by Reddy (8) evidences a lack of standard criteria regarding the methodology of calibration, a difficult task, given the large number of parameters involved in building's environmental and energy behavior. Additional contributions by Reddy et al. (9) identify the most influential parameters in fitting and its impact on experimental results; others by Raftery et al. (10) (11) explain the need for in situ measurements and a new zoning method providing a more exhaustive representation of the real model. In contrast, O'Neill et al. (12) use a metaevaluation that identifies influential parameters and the need for available weather data and solar radiation information.

One of the most influential factors to take into account is that of users and their occupational habits (working days or holidays). In many cases this is related both to the num- ber of occupants and their work or educational obligations, and to social customs and climatic reasons. Overall it is also connected with energy consumption habits (13) (14), mostly related to the operational conditions mentioned earlier and the socio-economic conditions of the inhabitants (15), as well as the energy efficiency of their systems and equipment. It is extremely difficult to obtain precise information on these variables, causing uncertainty on the results of the calibration process. As Tweed (16) states, housing refurbishment is affected by social aspects as well as by the technical ones.

Another concern arising when carrying out the calibration process is the criteria adopted in order to establish when the model is calibrated (17). Many case studies attempt to establish new methods for correlating simulation results with available measured data (not only for residential units), and analyzing and quantifying the error or deviation obtained (18). This may result in a major process which authors including Reddy et al. (9), O'Neill et al. (12) and Booth et al. (19) have simplified, reducing the complexity of the calibration and the time spent on it.

Many of these difficulties are overcome in this study based on the calibration of an energy model created from a case study of a multi-family dwelling occupied by a three-member middle-class family within a national heritage interest residential complex, which was monitored for a year under real-time operating conditions, in the southern Spanish city of Seville, with Mediterranean climate. This paper describes the methodology adopted as well as the calibration results obtained.

\section{CASE STUDY}

The analyzed building, "La Estrella", is a housing complex in Seville, in climate zone B4 (20), built between 1955 and 1963 by Medina Benjumea brothers, members of the OTAISA group of architects. The residential complex consists of 432 residential units, commercial premises and storage rooms on the ground floor (Figure 1a), and is a remarkable example of Spanish Modern Architecture, included in the Docomomo Ibérico database (21) and the Building Heritage of Andalusia database under registration number 01410910216 (22).

The star-shaped buildings of the residential complex represent a new interpretation of H-block typology, made up of three wings connected with a central vertical core (Figure 1b). This plan provides a wide variety of orientations for the dwellings and a double corridor, which provides crossed ventilation indoors.

The envelope's solution is an accessible inverted roof and a double-layer brick façade with an intermediate air chamber, an improvement on the widespread 1950s constructive solution of single-layer brick walls. The façade has undergone many individual changes in its openings, as the original wood frames and single glazing were replaced by metal frames with single or double glazing (Table 1).

Data from environmental parameters were collected for a year in real-time occupancy conditions in two residential units from the complex, located on the first floor in block 2, with an approximate surface area of $100 \mathrm{~m}^{2}$. 

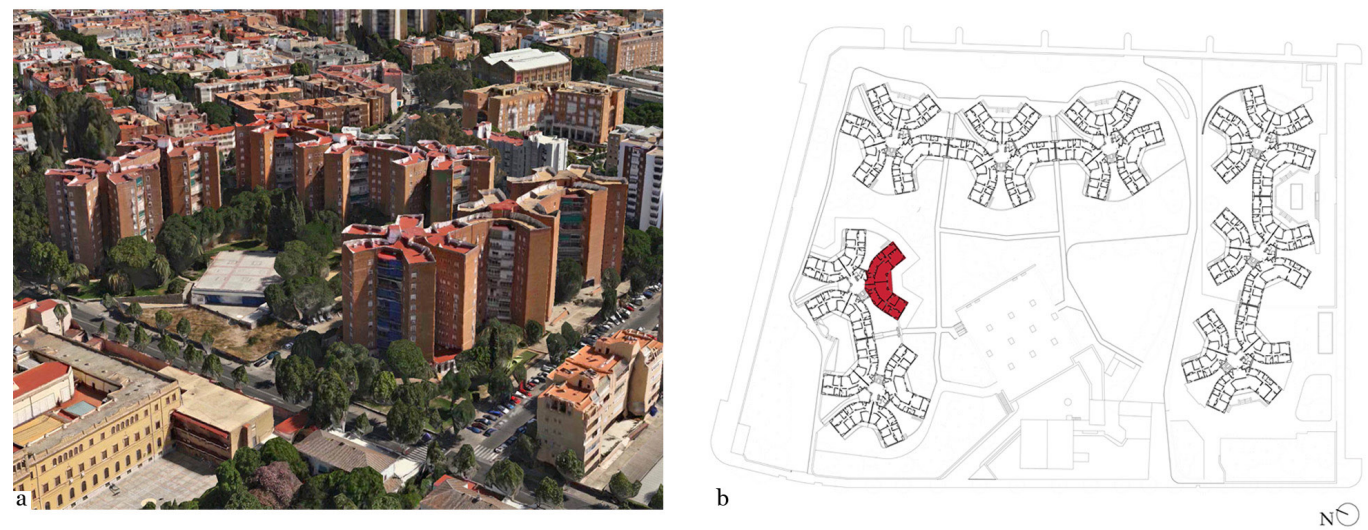

Figure 1. a. Birdseye view of residential complex La Estrella. b. Plan of residential complex with monitored dwellings.

Table 1. Thermal envelope definition of monitored dwellings.

\begin{tabular}{|c|c|c|c|}
\hline \multicolumn{2}{|c|}{ BUILDING ENVELOPE } & $\mathbf{U}\left(\mathbf{W} / \mathbf{m}^{2} \mathbf{K}\right)$ & $\begin{array}{c}U_{\lim }\left(W / \mathbf{m}^{2} K\right) \\
\text { DB HE1 }\end{array}$ \\
\hline \multicolumn{2}{|c|}{ Brick-faced wall, air chamber and hollow brick plastered partition } & & $\mathrm{U}_{\text {Wlim }}=0.82$ \\
\hline \multicolumn{2}{|l|}{ Floors } & & $\mathrm{U}_{\text {Flim }}=0.52$ \\
\hline \multicolumn{2}{|c|}{ Hollow brick plastered wall (connected to common areas) } & .85 & $\mathrm{U}_{\text {Wlim }}=0.82$ \\
\hline \multirow{2}{*}{$\begin{array}{l}\text { Bedroom } \\
\text { (5\% openings) }\end{array}$} & Onening Double-glazing 666 Metal frame & $\mathrm{U}_{\mathrm{O}}$ & \multirow{2}{*}{$\begin{array}{l}\mathrm{U}_{\text {Olim }, \mathrm{N}, \mathrm{NE}, \mathrm{NW}}=5.4 \\
\mathrm{U}_{\text {Olim } \mathrm{E}, \mathrm{W}}=5.7 \\
\mathrm{U}_{\text {Olim }, \mathrm{S}, \mathrm{SE}, \mathrm{SW}}=5.7\end{array}$} \\
\hline & Opening. Single glazing 4 - $6 \mathrm{~m}$ & $\mathrm{U}_{\mathrm{O}}=5$ & \\
\hline \multirow{2}{*}{$\begin{array}{l}\text { Living-room } \\
\text { (18\% ope- } \\
\text { nings) }\end{array}$} & 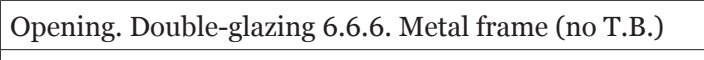 & $\mathrm{U}_{\mathrm{O}}=3.61$ & \multirow{2}{*}{$\begin{array}{l}\mathrm{U}_{\text {Olim }, \mathrm{N}, \mathrm{NE}, \mathrm{NW}}=3.8 \\
\mathrm{U}_{\mathrm{Olim}, \mathrm{E}, \mathrm{W}}=4.9 \\
\mathrm{U}\end{array}$} \\
\hline & Opening. Single glazing 4- $6 \mathrm{~mm}$. Metal frame (no T.B.) & $\mathrm{U}_{\mathrm{o}}=5.70$ & \\
\hline
\end{tabular}

The residential units show a high level of air-tightness so that there are only minor air leaks. There is a lack of mechanical or hybrid ventilation, and bathroom shunts are currently sealed, which results in deficient indoor air quality conditions.

Collective housing buildings in the Mediterranean area do not usually have air-conditioning systems (heating and/or cooling) or centralized systems for whole buildings or single dwellings. The monitored residential units only have a split heat pump, a small heater in the living room and an electric radiator in the bedroom, whose occasional use has been recorded.

In Table 2, the main climate data of Seville, obtained from the observation service of the State Meteorology Agency (AE-

Table 2. Standard Climate Values for Seville Airport (period 1981-2010)

\begin{tabular}{|c|c|c|c|c|c|c|c|}
\hline Month & $\mathbf{T}$ & TM & Tm & $\mathbf{R}$ & $\mathbf{H}$ & DR & I \\
\hline January & 10.9 & 16.0 & 5.7 & 66 & 71 & 6.1 & 183 \\
\hline February & 12.5 & 18.1 & 7.0 & 50 & 67 & 5.8 & 189 \\
\hline March & 15.6 & 21.9 & 9.2 & 36 & 59 & 4.3 & 220 \\
\hline April & $17 \cdot 3$ & 23.4 & 11.1 & 54 & 57 & 6.1 & 238 \\
\hline May & 20.7 & 27.2 & 14.2 & 30 & 53 & 3.7 & 293 \\
\hline June & 25.1 & 32.2 & 18.0 & 10 & 48 & 1.3 & 317 \\
\hline July & 28.2 & 36.0 & 20.3 & 2 & 44 & 0.2 & 354 \\
\hline August & 27.9 & 35.5 & 20.4 & 5 & 48 & 0.5 & 328 \\
\hline September & 25.0 & 31.7 & 18.2 & 27 & 54 & 2.4 & 244 \\
\hline October & 20.2 & 26.0 & 14.4 & 68 & 62 & 6.1 & 216 \\
\hline November & 15.1 & 20.2 & 10.0 & 91 & 70 & 6.4 & 181 \\
\hline December & 11.9 & 16.6 & 7.3 & 99 & 74 & 7.5 & 154 \\
\hline \multicolumn{8}{|c|}{$\begin{array}{l}\left.\text { Key: T (Monthly/Annual average temperatures }\left({ }^{\circ} \mathrm{C}\right)\right) ; \mathrm{TM} \text { (Monthly/Annual } \\
\left.\text { average of maximum daily temperatures }\left({ }^{\circ} \mathrm{C}\right)\right) ; \mathrm{Tm}(\mathrm{Monthly} / \text { Annual } \\
\left.\text { average of minimum daily temperatures }\left({ }^{\circ} \mathrm{C}\right)\right) ; \mathrm{R}(\mathrm{Monthly} / \text { Annual average } \\
\text { rainfall (mm)); H (Average relative humidity }(\%)) ; \mathrm{DR} \text { (Monthly/Annual } \\
\text { average number of rainfall days equal or greater to 1mm); I (Monthly/ } \\
\text { Annual average number of hours of sunshine). }\end{array}$} \\
\hline
\end{tabular}

MET) in San Pablo Airport (23), are shown. The weather conditions are mainly Mediterranean, with some continental features, with very hot dry summers and mild winters. January is the coolest month, with minimum average temperatures of $5.7^{\circ} \mathrm{C}$, and July is the hottest, with maximum daily average temperatures of $36^{\circ} \mathrm{C}$. Rainfall often occurs between April and October and December is the wettest month in the year.

\section{METHODOLOGY}

For the calibration of the energy model generated to simulate environmental and energy performance of the case study, a methodology consisting of the following four tasks was followed: monitoring the residential units for a year in real-time occupancy and operating conditions; in situ tests; energy model generation to reproduce the rooms analyzed in their actual state; and finally, the energy model calibration process.

The present paper explains the energy model calibration results used for dwelling "A", with a predominantly southeast orientation (Figure 2a).

\subsection{Monitoring}

The monitoring campaign adopts the same methodology developed in companion works by research group TEP-130 of Seville University (24). This task aimed to record environmental indoor data and analyze their evolution over a year (from April 1, 2013 to March 31, 2014). UNE-EN ISO 7726:2002 (25) protocol was followed in the monitoring process. Indoor air temperature and relative humidity data were collected every 30 minutes using wireless devices with sensors located in the living room and the main bedroom. Outdoors, a weather center station also recorded outdoor air temperature, relative humidity data and wind speed and direction. 563,328 data items were collected during the year of monitoring (26). 


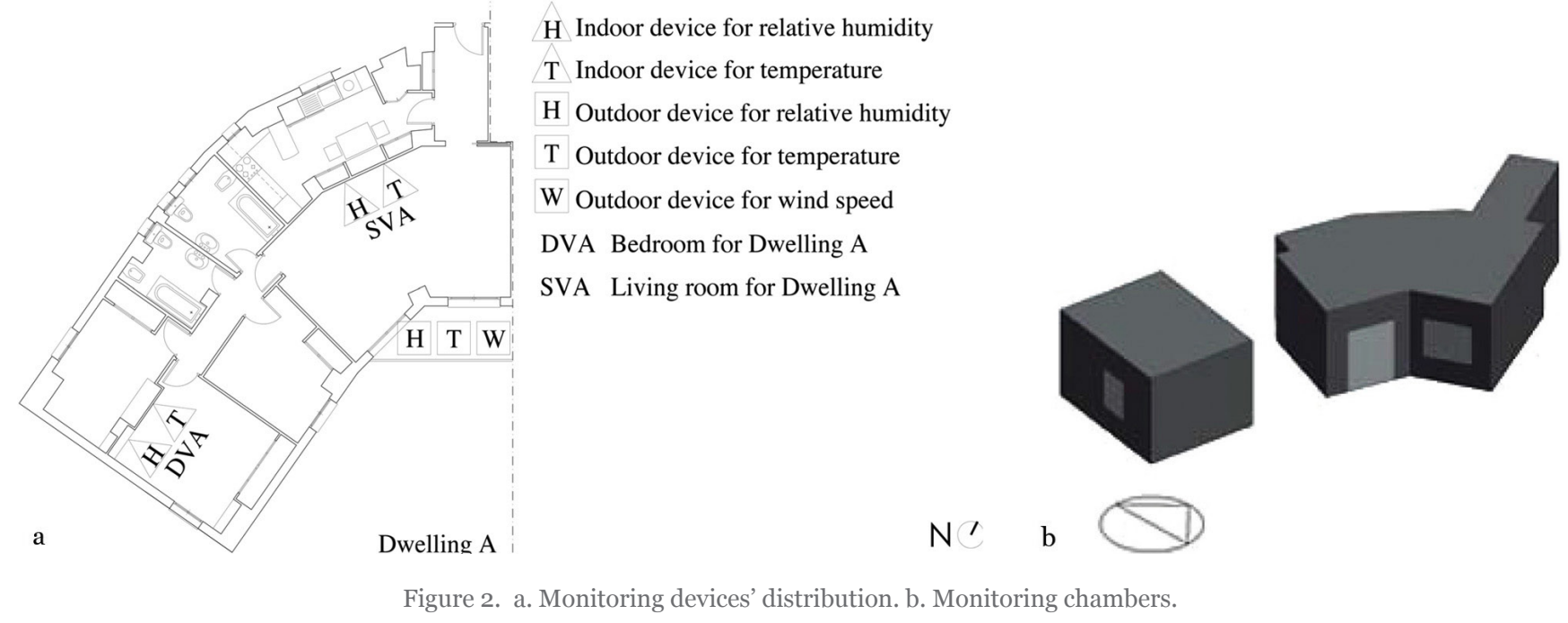

\subsection{Field tests}

A pressurization and depressurization trial was carried out in the dwelling, using Minneapolis Blower-Door Model 4/230V System equipment, to check the envelope air-tightness levels (27), following UNE EN 13829:2000 (28).

An infrared thermography study was also carried out to study thermal homogeneity, as well as to identify air leaks and whether thermal bridges are present or not in the envelope. Thermal images were analyzed with FLIR Systems ThermaCAM reporter (29) (30).

\subsection{Energy model generation}

The energy model was developed with DesignBuilder (v.2.4.2), which uses EnergyPlus (31), a simulation program recognized by the US DOE (32).

The energy model recreates the living room (day zone) and the bedroom (night zone) of the monitored residential unit in a simplified form, maintaining real orientation and weather data collected while monitoring (Figure 2b).

Location and climate conditions of Seville were considered when developing the energy model, as were the envelope's constructive definition and the dwelling's operating conditions: occupancy, real daily user profile, internal loads and hot and cold temperature set points.

As it is on the first floor of a nine-storey building, surrounded by other similar blocks from the same group, the residential unit is affected by the shadows cast by the blocks as well as vegetation. All rooms are exposed to outdoor conditions, with the only exception of the thermal envelope's part that remains connected to the common areas in the block (Figure $2 \mathrm{a}-2 \mathrm{~b}$ ). The residential unit is connected above to other similar dwellings, and below to commercial premises with no thermal insulation on the ground floor between them.

As the information was recorded under real-time conditions, the user had to be considered when generating the energy model. DesignBuilder allows the residential unit energy model to be supplemented with a complete description of the user's profile and the internal loads: occupancy data, lighting, and use of electric equipment. Table 3 shows input data schedules and distribution over the year. Furthermore, a natural ventilation schedule was established (Table 4) - as mentioned above, there is no other sort of ventilation system. Table 5 shows a schedule for the use of solar protection in the bedrooms, the common solar protection system in collective housing in southern Spain (Table 5). These Tables reflect the annual distribution of the user's energy consumption habits, information that was obtained from the users through various surveys over the year.

Three schedules were established for natural ventilation: Winter, Daytime, Night-time (Table 4). August was considered an exception as the only month in which the dwelling is unoccupied and unventilated during vacations.

Solar protection followed an all-or-nothing (o-10o \%) schedule for opening and closing the blinds, and the annual distribution is shown in Table 5 . This mostly coincides with real use.

Once the user's calendar was confirmed and usage and operating conditions were established in the energy model in-

Table 3. Real user occupancy, lighting and equipment schedules. Annual distribution.

\begin{tabular}{|l|l|l|l|l|}
\hline SCHEDULE & \multicolumn{1}{|c|}{ OCCUPANCY } & \multicolumn{1}{c|}{$\begin{array}{c}\text { ELECTRIC } \\
\text { EQUIPMENT }\end{array}$} & \multicolumn{2}{c|}{$\begin{array}{c}\text { ANNUAL } \\
\text { DISTRIBUTION }\end{array}$} \\
\hline Working days & oh-8h \& 14h-16h \& 19h-24h & $7 \mathrm{~h}-8 \mathrm{~h} \& 14 \mathrm{~h}-16 \mathrm{~h} \&$ 19h-24h & Jan.-Jun.; Oct.-Dec. & \multirow{2}{*}{ M-F } \\
\hline Holidays & oh-8h \& 14h-24h & $7 \mathrm{~h}-8 \mathrm{~h} \& 14 \mathrm{~h}-24 \mathrm{~h}$ & Jul.; Sep. & \\
\hline Weekend & oh-12h \& 19h-24h & 10h-13h \& 19h-24h & Jan.-Apr.; Oct.-Dec. & \multirow{2}{*}{ S-SD } \\
\hline Off & Unoccupied & Equipment not used & May-Jul.; Sep. & M-SD \\
\hline Off & Unoccupied & Equipment not used & Aug. & \\
\hline${ }^{*}$ This involves electric equipment and lighting but not air-conditioning systems & & \\
\hline
\end{tabular}


Table 4. Natural ventilation schedules in real-time occupancy conditions. Annual distribution.

\begin{tabular}{|c|c|c|c|c|c|}
\hline SCHEDULE & \multicolumn{4}{|c|}{ NATURAL VENTILATION } & $\begin{array}{c}\text { ANNUAL } \\
\text { DISTRIBUTION }\end{array}$ \\
\hline Winter & M-F & $8 \mathrm{~h}-9 \mathrm{~h}$ & S-SD & 10h-11h & Jan.-Mar.; Oct.-Dec. \\
\hline Daytime & M-F & $8 \mathrm{~h}-14 \mathrm{~h} \& 19 \mathrm{~h}-24 \mathrm{~h}$ & S-SD & 1oh-13h \& 19h-24h & Apr.-May \\
\hline Nighttime & M-F & \multicolumn{3}{|l|}{ oh-8h \& 2oh-24h } & Jun.-Jul.; Sep. \\
\hline Off & S-SD & \multicolumn{3}{|c|}{ Natural ventilation not activated } & Jun.-Jul.; Sep. \\
\hline Off & M-SD & \multicolumn{3}{|c|}{ Natural ventilation not activated } & Aug. \\
\hline
\end{tabular}

corporating the various surveys provided by users over the year, uncertainties in the energy model calibration process were greatly reduced. However, the remaining doubts can be summed up as follows:

- Energy flow throughout the façade walls, including openings. Given the residential unit's first-floor location, uncertainties arise when quantifying the effect of surrounding vegetation on the thermal envelope, both on built and glazed surfaces.

- Energy flow throughout other components of the thermal envelope. Partition walls between residential units have been considered adiabatic. The framework that separates the residential unit from the commercial premises on the ground floor, considered to be uninsulated, is an element that casts doubts on the analysis of the thermal performance: whether it is adiabatic or if there is heat transfer through it.

- Ventilation. Uncontrolled ventilation is one of the most significant parameters in dwelling's energy balance (13). The infiltration rates considered were those measured in situ using Blower Door equipment to quantify air permeability. However, as natural ventilation depends on windows opening as stated in the surveys carried out among the users (Table 4), the total air changes per hour when the residential unit is ventilated remain unknown.

Regarding the above considerations, a sensitivity analysis was carried out, based on two prior hypotheses in order to define the energy model, according to the different environmental conditions which affect heat transfer performance between indoors and outdoors (the outdoor vegetation and surrounding blocks, and their influence on solar radiation, as well as the contact with the uninsulated space on the ground floor mentioned above):

- Hypothesis 01 (Ho1): The aim of this hypothesis was to see how far a simplified model could match real conditions, generating a cell model to represent the spaces monitored (Figure 2a-2b). The first-floor framework was considered adiabatic and no solar protection effects from the surrounding blocks or vegetation were taken into account. In order to rule out the effect of the third parameter, ventilation, this analysis was only applied to August, when as mentioned above, the residential unit was unoccupied, so

Table 5. Annual distribution of solar protection schedules. SOLAR PROTECTION SCHEDULE (Blinds)

\begin{tabular}{|l|l|l|l|}
\hline M-SD & Jan.-May; Oct.-Dec. & Daytime & 8h-18h \\
\hline M-F & Jun.-Jul.; Sep. & Night-time & oh-8h \& 20h-24h \\
\hline S-SD & Jun.-Jul.; Sep. & On (100 \%) & oh-24h \\
\hline M-SD & Aug. & On (100 \%) & oh-24h \\
\hline
\end{tabular}

that the influence of a zero natural ventilation rate was analyzed (Table 4).

- Hypothesis 02: Once the results of the simplified model were assessed, a second hypothesis was considered, consisting in a more complete model version to account for environmental conditions. In this, the thermal transfer through the first-floor framework, and the solar protection were considered, as well as the shade provided by the blocks and vegetation to the dwellings, keeping in mind the use of blinds shown in Table 5. Here, the aim was to analyze the effect of solar radiation in indoor dwelling conditions, again ruling out the effect of natural ventilation. The study was therefore performed for the same month, August, with the same natural ventilation conditions as in $\mathrm{Ho1}$, that is, $\mathrm{OACH}$.

Furthermore, once the results of Ho1 and Ho2 were assessed, a final analysis was carried out, starting from the model in this second hypothesis, which reflected users' calendars and energy consumption habits. A calibration process was developed in order to incorporate the effect of natural ventilation, whose presence in this particular type of residence does not only have an environmental meaning but also a cultural one, as it is a widespread method of environmental control in collective housing stock in the Mediterranean area (33).

Although a natural ventilation usage calendar was constructed using the data from the user surveys (Table 4), it was not possible to quantify intensity, measured in air change per hour rates which also vary throughout the year, depending on general climate conditions. Owing to this, this analysis used different ventilation rates for input data: $0,0.5,1,2,3$ and $4 \mathrm{ACH}$, for each month analyzed, that is, May (intermediate season), June (summer) and January (winter), following the order of the monitoring campaign, studying the effects of the different rates on the model.

\section{DISCUSSION OF RESULTS}

Starting from the energy model generated for the calibration process, the results for Ho1 and Ho2, as well as the subsequent sensitivity analysis applied to summer, winter and intermediate season months, are assessed. The simulation and monitoring of temperatures are both compared in freeevolution conditions, that is, without using heating or cooling systems. The aim of this task is to see which model best fits real energy performance.

The overall focus of this analysis is on the indoor temperature ranges obtained for each different hypothesis, but it is equally important to observe temperature trend. It is difficult to get a complete match because of user habits, despite the best efforts to identify these through surveys throughout the year. 


\subsection{Hypothesis 01}

The results of the energy model simulation for each of the rooms were analyzed, assuming that heat transfer was only taking place through external walls (Figure $2 b$ ), as the other partitions connected to adjacent spaces with different consumption were considered adiabatic (Table 6).

Given the existence of a blind box in the openings of the spaces monitored and following correction and conversion to atmospheric pressure, the results for the in situ air-tightness tests gave an infiltration rate ranging between 0.23 and 0.54 $\mathrm{ACH}$, which were acceptable values. Indoor air quality, however, was very poor given the lack of functioning ventilation systems, with the only ventilation provided by open windows.

Figure 3 represents simulated indoor temperature evolution and indoor and outdoor data monitored in the energy models analyzed (bedroom and living room, with south and southeast orientations, respectively) in August, with zero natural ventilation rate. The results show major discrepancies between simulated and monitored data, from 5 to $7^{\circ} \mathrm{C}$ in the bedroom, and from 10 to $12{ }^{\circ} \mathrm{C}$ in the living room.

Given that the residential unit is located on a first floor, the lack of solar protection provided by the blocks and vegetation is the main cause of temperatures' dispersion. Additionally, the fact that every partition except the envelope was considered adiabatic, even the first-floor framework in contact with the uninsulated commercial premises on the ground floor, has caused a greater heat accumulation indoors, with a delayed effect on indoor temperatures. Consequently, this simplified model (hypothesis 01) is not satisfactory, so that hypothesis 02 , which embodies environmental conditions, is needed.
Table 6. Monitored spaces energy model input data.

\begin{tabular}{|l|l|l|}
\hline \multicolumn{3}{|c|}{ HYPOTHESIS o1. Input data } \\
\hline Adjacencies & $\begin{array}{l}\text { Adiabatic. Energy flow only through external } \\
\text { partitions }\end{array}$ \\
\hline \multirow{2}{*}{ Infiltrations } & Bedroom & 0.54 ACH (with blind box) \\
\cline { 2 - 3 } & Living room & 0.23 ACH (without blind box) \\
\hline Months analyzed & \multicolumn{2}{c}{ August } \\
\hline
\end{tabular}

\subsection{Hypothesis 02}

This calibration model incorporates thermal transfer through the floor of the monitored spaces in contact with the uninsulated commercial premises on the ground floor. The model has been supplemented with elements from the immediate surroundings of the dwelling, to check the effect of solar radiation on the monitored spaces, including the other blocks in the complex and vegetation as generators of shade (Table 7).

Figure 4 shows the simulated indoor temperature in each different space and indoor and outdoor monitored data, in August, with the same natural ventilation rate as in hypothesis 01 .

The results obtained for this second hypothesis show a better match of the simulated energy model, with only a minimum difference of 0.5 to $1{ }^{\circ} \mathrm{C}$ between monitored and simulated indoor temperatures in both spaces. The consideration of

Table 7. Monitored spaces energy model input data.

\begin{tabular}{|l|l|l|}
\hline \multicolumn{2}{|c|}{ HYPOTHESIS o2. Input data } \\
\hline \multirow{2}{*}{ Adjacencies } & \multicolumn{2}{|l|}{$\begin{array}{l}\text { Adiabatic. Energy flow through external walls } \\
\text { and first-floor framework }\end{array}$} \\
\hline \multirow{2}{*}{ Infiltrations } & Bedroom & $0.54 \mathrm{ACH}$ (with blind box) \\
\cline { 2 - 3 } & Living room & $0.23 \mathrm{ACH}$ (without blind box) \\
\hline Months analyzed & \multicolumn{2}{c}{ August } \\
\hline
\end{tabular}

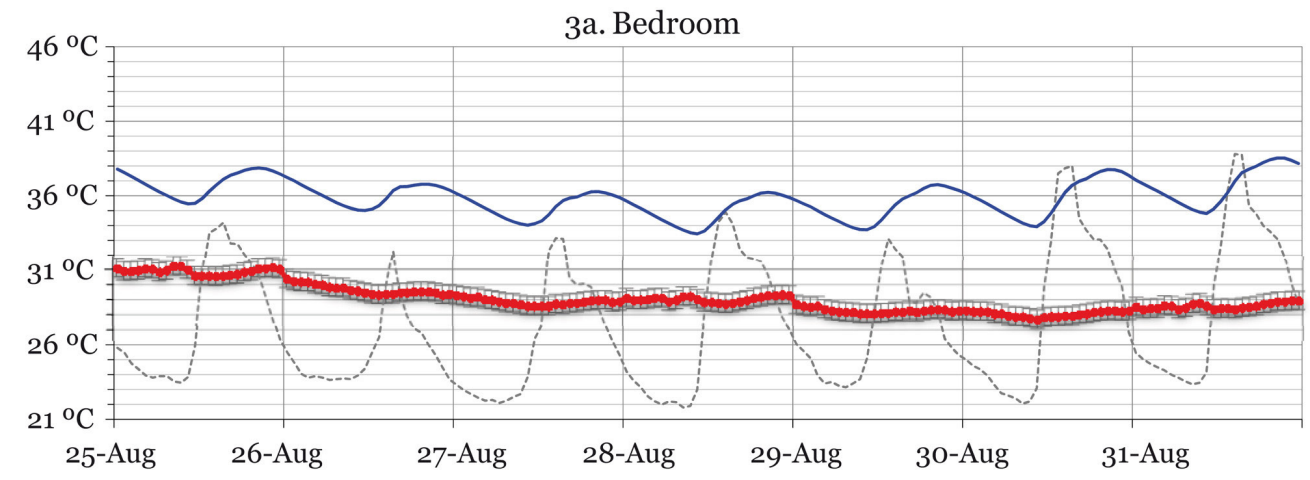

3b.Living-room

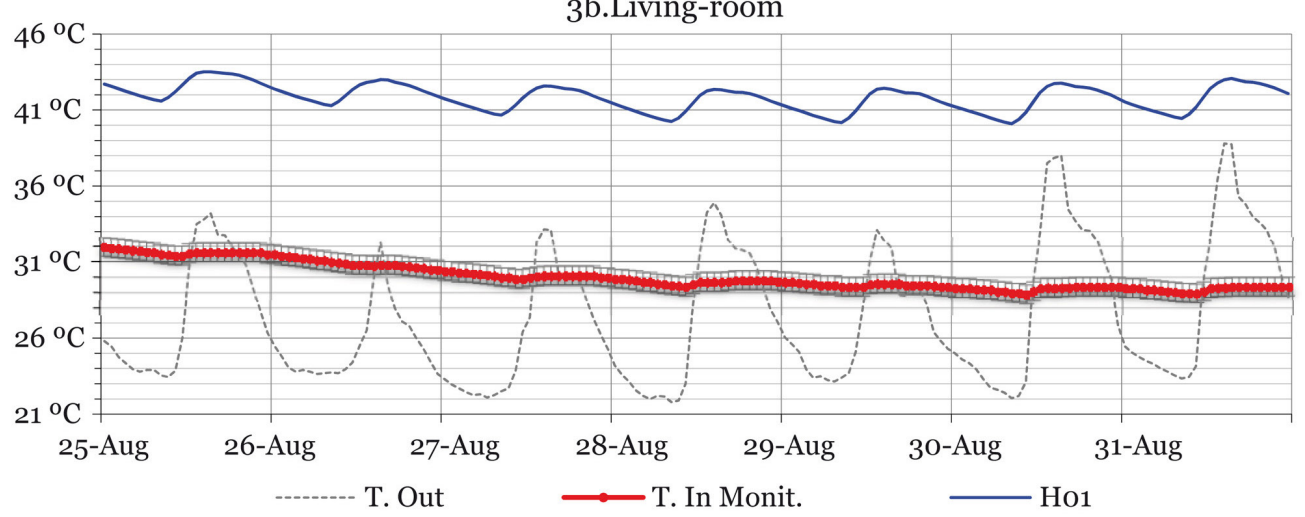

Figure 3. Simplified energy model, monitored and simulated indoor temperature (August). 


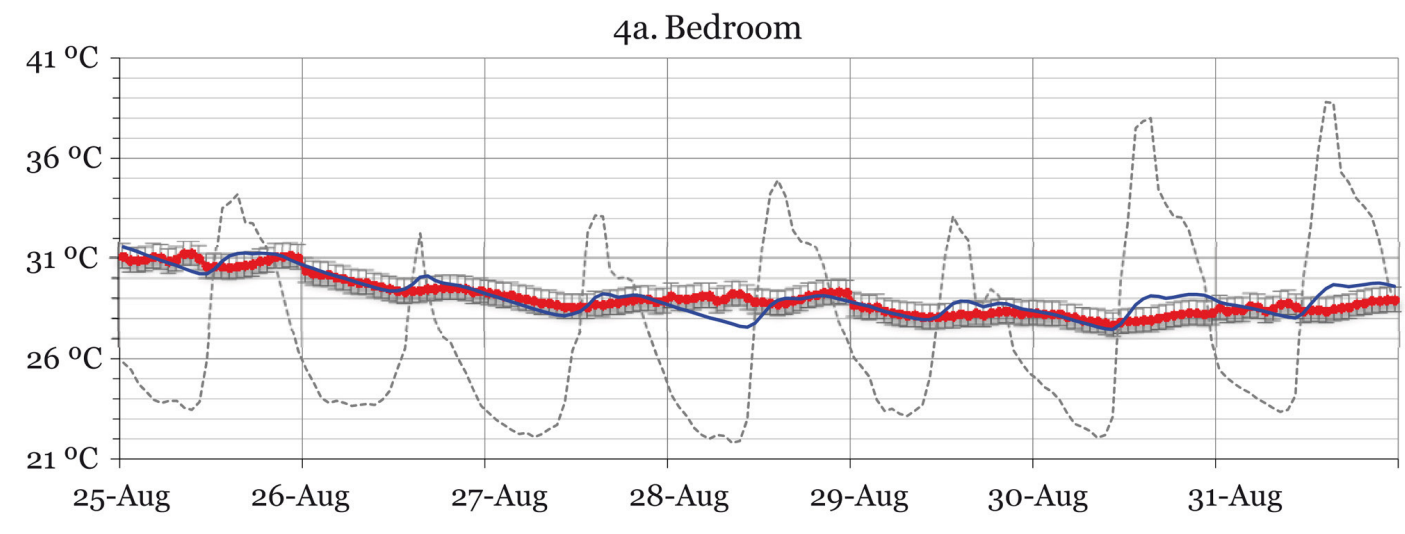

4b. Living-room

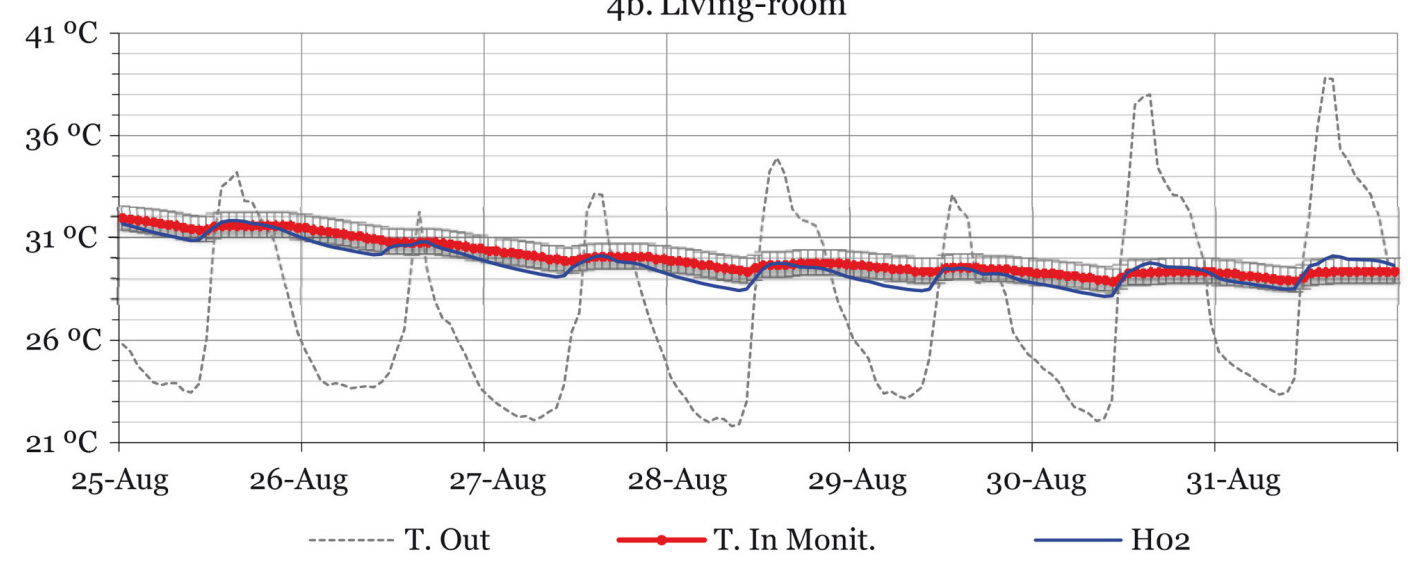

Figure 4. Hypothesis 02. Monitored and simulated indoor temperature (August).

the surrounding elements limits solar exposure in the energy models, and therefore daytime energy gains, which translates into a sharp decrease in simulated indoor temperature values and a better match to the monitored data. Moreover, considering the energy flow through the first-floor framework in contact with the commercial premises on the ground floor reduces thermal storage.

These results suggest two main ideas: the particularly significant lack of agreement when simplified models are used, which is very common when using simulation tools to predict thermal and energy performance in buildings, and the determining fact that is the first-floor location of the residential unit, surrounded by shading elements limiting solar exposure, which should be kept in mind when assessing behavior.

\subsection{Calibration}

After the assessment of the energy model performance in Ho2 for August, with the residential unit unoccupied, from which it can be concluded that the energy model works for the preestablished conditions, it is time to evaluate how far user and energy consumption habits (Table 3) affect the energy model, particularly the use they make of natural ventilation to improve indoor air quality (Table 4). As natural ventilation intensity measured in air changes per hour not only depends on how far windows are open, but also on outdoor climate conditions, the main objective is to assess which air change rate best fits the real model, keeping available measured data in mind. This analysis was carried out introducing different ventilation rate values as energy model input data: $0,0.5,1,2,3$ and $4 \mathrm{ACH}$, for each of the three months of the year analyzed: May (intermedi- ate season), June (summer) and January (winter), following the order of the monitoring campaign (Table 8).

Figures 5, 6 and 7 represent simulated indoor temperature evolution in each different room and indoor and outdoor monitored data for the months of May, June and January, with various ventilation rates from o to $4 \mathrm{ACH}$.

As expected, in general, the results obtained in this case do not show the same fit as Ho2 in August (Figure 4), when the residential unit was empty. This information shows how difficult ventilation control in these months can be, when it is almost impossible to get an exact fit between monitored and simulated indoor conditions.

In May, the intermediate season, simulation results in both rooms show a clear match with a ventilation rate from 0 to 1 $\mathrm{ACH}$, during the hours when the residential unit is ventilated (Table 4), fluctuating from 1 to $2{ }^{\circ} \mathrm{C}$ up or down from the oth-

Table 8. Energy model input data. Calibration.

\begin{tabular}{|l|l|l|}
\hline \multicolumn{3}{|c|}{ CALIBRATING ENERGY MODEL. Input data } \\
\hline Adjacencies & $\begin{array}{l}\text { Adiabatic. Energy flow through external walls and } \\
\text { first-floor framework }\end{array}$ \\
\hline \multirow{2}{*}{ Infiltrations } & Bedroom & $\begin{array}{l}\text { o.54 ACH (with blind } \\
\text { box) }\end{array}$ \\
\cline { 2 - 3 } & Living room & $\begin{array}{l}\text { o.23 ACH (without } \\
\text { blind box) }\end{array}$ \\
\hline Ventilation & $\begin{array}{l}\text { Sensitivity analysis } \\
\text { varying air renewing rates }\end{array}$ & 0, 0.5, 1, 2, 3, 4 ACH \\
\hline $\begin{array}{l}\text { Months } \\
\text { analyzed }\end{array}$ & \multicolumn{2}{|c|}{ May, June, January } \\
\hline
\end{tabular}



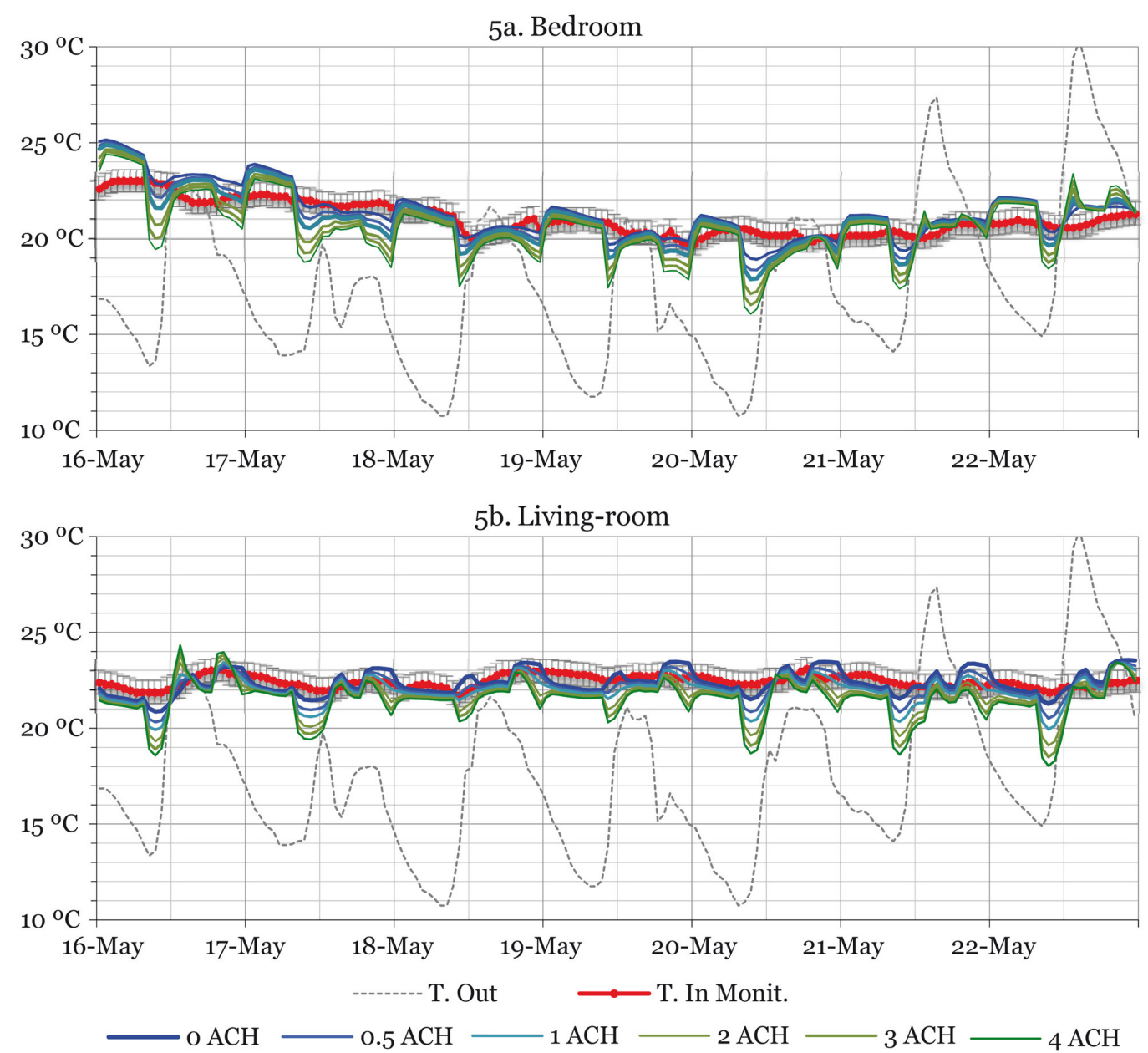

Figure 5. Indoor temperature match according to ventilation rates (May).

er rates, essentially when windows are open (Figure 5). When ventilation comes into play, there is a sharp leap in indoor temperatures, which almost reach outdoor conditions. This is more noticeable in the bedroom than in the living room.

In June, in the bedroom, the fitting occurs with an air renovation rate of $4 \mathrm{ACH}$, with differences of about $2{ }^{\circ} \mathrm{C}$ between monitored and simulated indoor data, while in the living room the match is clearer for a 1 to $2 \mathrm{ACH}$ ventilation rate, maintaining a difference of about $2-3{ }^{\circ} \mathrm{C}$ between temperatures (Figure 6). For both rooms, during the daytime, simulated and monitored indoor data are closer together, whereas at night-time, simulated indoor data are sensitively lower, regardless of the ventilation rate adopted.

In January, observing the simulated indoor temperature tendency with different ventilation rates (Figure 7), the model that fits best is that with a $\mathrm{O} \mathrm{ACH}$ rate, considering outdoors climate conditions. Temperature tendencies almost go hand in hand with those of the monitored data, and in general, a difference of $2{ }^{\circ} \mathrm{C}$ between the simulated and monitored indoor temperature is observed in both rooms, sometimes exceeding $3{ }^{\circ} \mathrm{C}$ when heating equipment is on, as can be observed by sharp leaps in the monitored indoor temperature.

To sum up, the Ho2 model, with a ventilation schedule based on user surveys (Table 4) can achieve a suitable match between simulated environmental conditions and monitored ones, with different ventilation rates, according to the seasons of the year and user occupation.

\section{CONCLUSIONS}

Retrofitting energy strategies should be based on appropriate knowledge of the current state energy conditions. For this reason, it is essential to carry out a monitoring campaign and a subsequent match of energy models in a calibration process.

Calibration processes must be carried out at least on a monthly basis using hourly data. Detailed information is necessary in order to ensure as precise a calibration as possible. The calibration methodology followed in this paper shows that fitting involves decreasing the number of uncertain parameters and individually assessing their effect on the energy model using sensitivity analysis.

In a B4 climatic zone, it is obvious that solar radiation, mostly through the envelope's openings, is a determinant factor. As a result, when it comes to the generation of energy models for residential units in a Mediterranean climate it is essential to keep in mind absolutely all environmental conditions which may provide shade, including vegetation. Moreover, it is equally necessary to assess air infiltration effects in the dwellings, so that in situ air-tightness tests are indispensable for decreasing the level of uncertainty in energy model generation. 

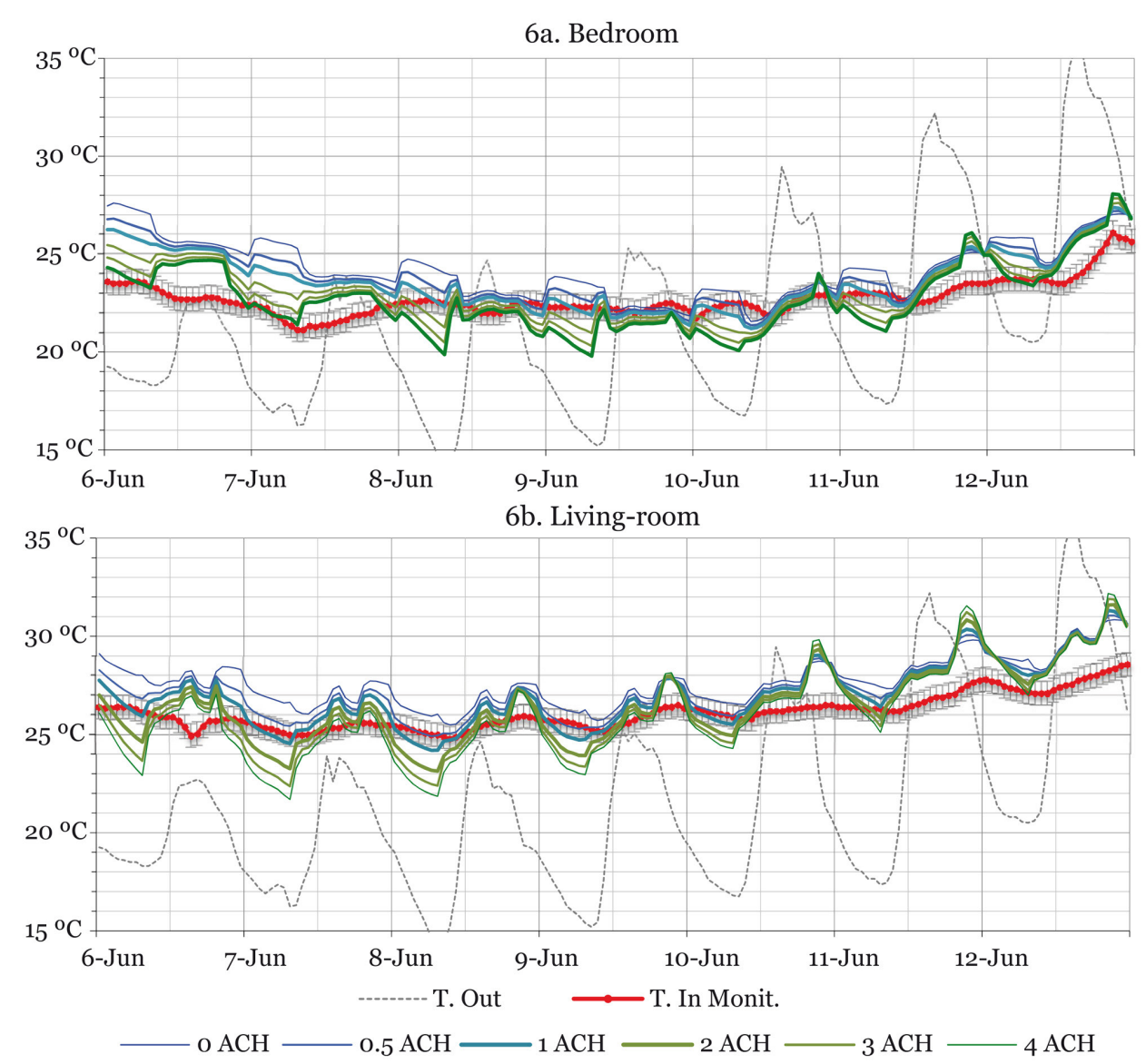

Figure 6. Indoor temperature match according to ventilation rates (June).

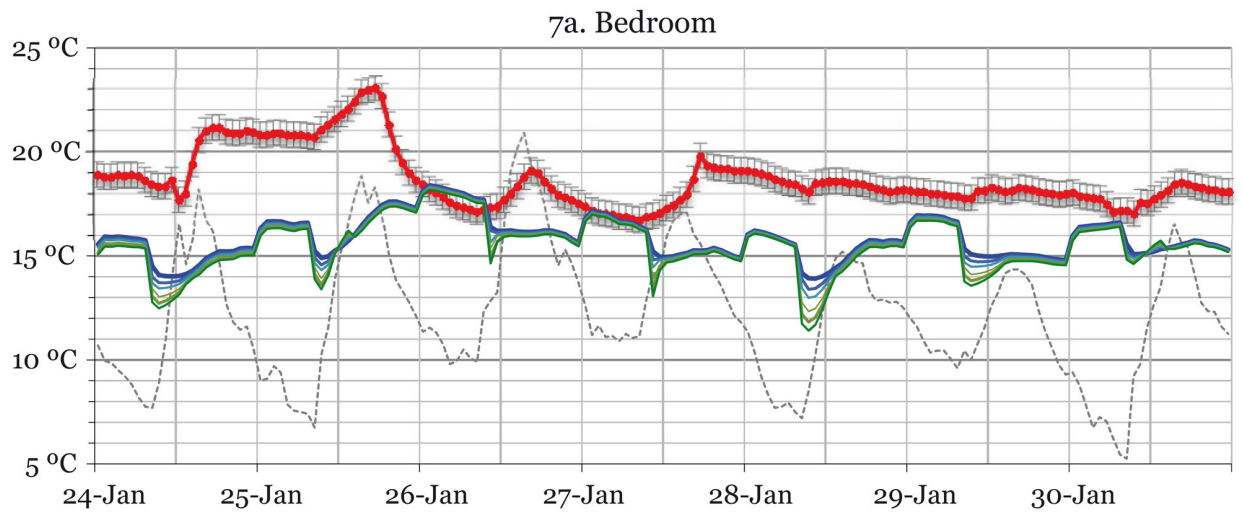

7b. Living-room

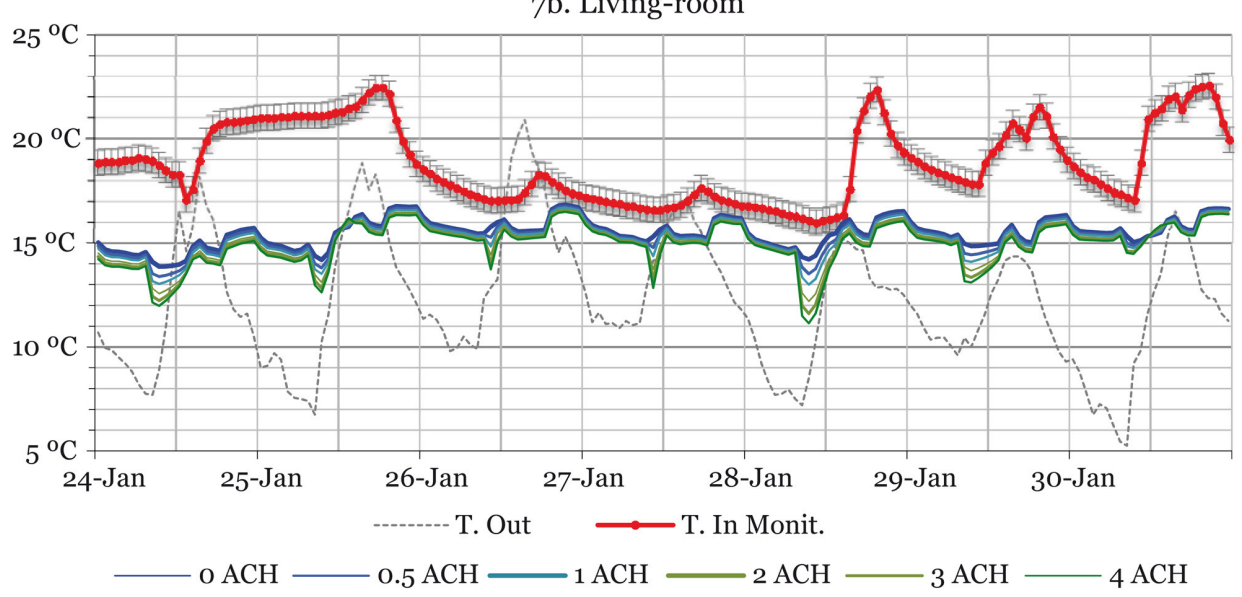

Figure 7. Indoor temperature match according to ventilation rates (January). 
Measuring real occupancy conditions includes the effect of the users, whose actions also affect the other parameters, and contribute to a higher matching error when the importance of the user is not fully considered. Although carrying out energy consumption habit surveys among users decreases uncertainty, it is necessary to ensure their accuracy. Adding devices such as window opening contactors may be of great help, as they can offer useful information about when natural ventilation, often used in Mediterranean climates, comes into play. This paper shows that establishing ventilation rates on a seasonal basis can have a significant effect on energy model calibration.

\section{ACKNOWLEDGEMENTS}

This work has been financially supported by the Spanish Government, with reference BIA2012-39020-C02-01.

\section{REFERENCES}

(1) CENER. (2014). Estudio T-nZEB: Transformación de Edificios Existentes hacia Edificios de Consumo Casi Nulo, p. 15, Madrid: Departamento de Energética Edificatoria. Centro Nacional de Energías Renovables.

(2) EUR-Lex. (2011, 11st of February ). Opinion "Energy poverty in the context of liberalisation and the economic crisis". Official Journal of the European Union, C44: 53-56. http://eur-lex.europa.eu/legal-content/EN/TXT/PDF/?uri=CELE $\mathrm{X}: 52010 A E 0990 \&$ from $=\mathrm{EN}$.

(3) EUR-Lex. (2012, 14th of November). Directive 2012/27/EU of the European Parliament and of the Council of 25 October 2012 on energy efficiency, amending Directives 2009/125/EC and 2010/30/EU and repealing Directives 2004/8/ EC and 2006/32/EC. Official Journal of the European Union, L315: 1-56. http://eur-lex.europa.eu/legal-content/EN/ TXT/PDF/?uri=CELEX:32012LO027\&rid=1.

(4) Cortes Generales. (2013). Ley 8/2013 de rehabilitación, regeneración y renovación urbanas. Boletín Oficial del Estado, $\mathrm{n}^{0}$ 153. Spain.

(5) Sendra, J. J, Domínguez, S., Bustamante, P., León, A.L. (2013). Energy intervention in the residential sector in the south of Spain: Current challenges. Informes de la Construcción, 65(532): 457-464, doi: http://dx.doi.org/10.3989/ic.13.074.

(6) Sunikka-Blank, M., Galvin, R. (2012). Introducing the prebound effect: the gap between performance and actual energy consumption. Building Research and Information, 40(3): 260-273, doi: http://dx.doi.org/10.1080/09613218.2012.690952.

(7) European Commission. (2015). New tools and methodologies to reduce the gap between predicted and actual energy performances at the level of buildings and blocks of buildings. http://ec.europa.eu/research/participants/portal/desktop/en/opportunities/h2020/topics/413-eeb-07-2015.html.

(8) Reddy, T. (2006). Literature review on calibration of building energy simulation programs: uses, problems, procedures, uncertainty and tools. ASHRAE Transactions, (112): 226-240.

(9) Reddy, T., Maor, I., Panjapornpon, C. (2007). Calibrating detailed building energy simulation programs with measured data - Part I: General methodology (RP-1051). HVAC\&R Research, 13(2): 221-241, doi: http://dx.doi.org/10.1080/1078 9669.2007.10390952.

(10) Raftery, P., Keane, M., O’Donnell, J. (2011). Calibrating whole building energy models: An evidence-based methodology. Energy and Buildings, 43(9): 2356-2364, doi: http://dx.doi.org/10.1016/j.enbuild.2011.05.020.

(11) Raftery, P., Keane, M., Costa, A. (2011). Calibrating whole building energy models: Detailed case study using hourly measured data. Energy and Buildings, 43(12): 3666-3679, doi: http://dx.doi.org/10.1016/j.enbuild.2011.09.039.

(12) O'Neill, Z., Eisenhower, B. (2013). Leveraging the analysis of parametric uncertainty for building energy model calibration. Building Simulation, 6(4): 365-377, doi: http://dx.doi.org/10.1007/s12273-013-0125-8.

(13) Sendra, J. J., Domínguez, S., León, A. L. (2011). Proyecto Efficacia: Optimización energética en la vivienda colectiva. Sevilla: Secretariado de Publicaciones de la Universidad de Sevilla, Emvisesa y Sodinur.

(14) Mortensen, A., Heiselberg, P., Knudstrup, M. (2014). Economy Controls Energy Retrofits of Danish Single-Family Houses. Comfort, Indoor Environment and Architecture Increase the Budget. Energy and Buildings, 72: 465-475, doi: http:// dx.doi.org/10.1016/j.enbuild.2013.12.054.

(15) Santamouris, M., Alevizos, S. M., Aslanoglou, L., Mantzios, D., Milonas, P., Sarelli, I., Karatasou, S., Cartalis, K., Paravantis, J. A. (2014). Freezing the poor-Indoor environmental quality in low and very low income households during the winter period in Athens. Energy and Buildings, 70: 61-70, doi: http://dx.doi.org/10.1016/j.enbuild.2013.11.074.

(16) Tweed, C. (2013). Socio-technical issues in dwelling retrofit. Building Research and Information, 41(5): 551-562, doi: http://dx.doi.org/10.1080/09613218.2013.815047.

(17) ASHRAE. (2002). ASHRAE Guideline 14-2002: Measurement of Energy and Demand Savings.

(18) van Ruijven, B., de Vries, B., van Vuuren, D. P., van der Sluijs, J. P. (2009). A Global Model for Residential Energy use: Uncertainty in Calibration to Regional Data. Energy, 35(1): 269-282, doi: http://dx.doi.org/10.1016/j.energy.2009.09.019.

(19) Booth, A. T., Choudhary, R., Spiegelhalter, D. T. (2011). Handling uncertainty in housing stock models. Building and Environment, 48: 35-47, doi: http://dx.doi.org/10.1016/j.buildenv.2011.08.016.

(20) De la Flor, F. J. S., Domínguez, S. A., Félix, J. L. M., Falcón, R. G. (2008). Climatic zoning and its application to Spanish building energy performance regulations. Energy\&Buildings, 40(10): 1984-1990, doi: http://dx.doi.org/10.1016/j. enbuild.2008.05.006.

(21) Docomomo Ibérico Foundation. Residential Complex La Estrella. http://www.docomomoiberico.com/index.php? option=com_k2\&view=item\&id=1008:conjunto-de-viviendas-la-estrella\&Itemid=11\&vista=1\&lang=es.

(22) IAPH (Patrimonio Inmueble de Andalucía). Residential Complex La Estrella. http://www.iaph.es/patrimonio-inmueble-andalucia/resumen.do?id=i17217.

(23) AEMET. http://www.aemet.es/es/serviciosclimaticos/datosclimatologicos/valoresclimatologicos? $1=5783 \& \mathrm{k}=$ and. $\quad$ (Last visit: 01-02-2015). 
(24) León, A. L., Muñoz, S., León, J., Bustamante, P. (2010). Monitoring environmental and energy variables in the construction of subsidized housing: Cros-Pirotecnia building in Sevilla. Informes de la Construcción, 62(519): 67-82, doi: http:// dx.doi.org/10.3989/ic.09.045.

(25) AENOR-CEN. (2002). UNE-EN ISO 7726, Ergonomics of the thermal environment - Instruments for measuring physical quantities. Asociación Española de Normalización (AENOR).

(26) Blázquez, T., Suárez, R. (2014). Experiencias de Monitorización de Vivienda Plurifamiliar de los Años Cincuenta en Sevilla. In Barbero-Barrera, M. M., Olivieri, F., Pinilla-Melo, J. (Ed.), Miradas a la investigación arquitectónica: construcción, gestión, tecnología, (pp. 289-293). Madrid: Escuela Técnica Superior de Arquitectura (ETSAM), Universidad Politécnica de Madrid.

(27) Fernández-Agüera, J., Sendra, J. J. (2011). Protocols for Measuring the Airtightness of Multi-Dwelling Units in Southern Europe. Procedia Engineering, 21: 98-105, doi: http://dx.doi.org/10.1016/j.proeng.2011.11.1992.

(28) AENOR-CEN. (1996). UNE-EN ISO 9972, Thermal performance of buildings - Determination of air permeability of buildings - Fan pressurization method. (ISO 9972:1996, modified). Asociación Española de Normalización (AENOR).

(29) AENOR-CEN. (1998). UNE-EN 13187:1998, Thermal performance of buildings. qualitative detection of thermal irregularities in building envelopes. Infrared method (ISO 6781:1983, modified). Asociación Española de Normalización (AENOR).

(30) ISO. (2008). ISO 18434-1:2008, Condition monitoring and diagnostics of machines - Thermography - Part 1: General procedures.

(31) U.S. Department of Energy. EnergyPlus Energy Simulation Software: http://apps1.eere.energy.gov/buildings/energyplus/.

(32) DOE (U. S. Department of Energy). http://www.energy.gov.

(33) Imessad, K., Derradji, L., Ait Messaoudene, N., Mokhtari, F., Chenak, A., Kharchi, R. (2014). Impact of passive cooling techniques on Energy demand for residential buildings in a Mediterranean climate. Renewable Energy, 71: 589-597, doi: http://dx.doi.org/10.1016/j.renene.2014.06.005. 